\title{
TÍTULOS DE CRÉDITO
}

\section{Píldoras creativas del Diseño Gráfico en el Cine}

\author{
Roberto Gamonal Arroyo (robertogamonal@yahoo.es) \\ Profesor de Periodismo y Comunicación Audiovisual. Universidad Complutense de Madrid \\ y Universidad Francisco de Vitoria.
}

AGRADECIMIENTO: a Xavi Bertran por cedernos los archivos digitalizados de los títulos de crédito y por su labor de recopilación en www.titulosdecrédito.org

\section{Resumen}

Los títulos de crédito se han convertido por méritos propios en un género cinematográfico particular. La calidad de algunos supera incluso a la propia película en la que están insertados. Pequeñas obras maestras que condensan en poco tiempo la introducción a la trama narrativa y la información de todos los profesionales que participan en el film mediante un uso creativo de la imagen y la tipografía fijas y/o en movimiento con el apoyo de la banda sonora, intentando crear un ambiente de predisposición en el espectador. Un nombre marca su evolución desde mediados del siglo XX hasta nuestros días: Saul Bass, el responsable de las mejores y más creativas secuencias iniciales del cine. Diseño Gráfico y Cine se dan la mano gracias al "hombre del trazo de oro”.

\section{Palabras clave}

Títulos de Crédito - Tipografía - Diseño Gráfico - Creatividad - Cine - Saul Bass

\begin{abstract}
The title sequences have become by own merits a particular cinematographic genre. The quality of some even surpasses to the own film in which they are inserted. Small masterpieces that condense
\end{abstract}


just a short time in the introduction to the narrative plot and the information of all the professionals which share in the film by means of a creative use of the static and/or moved image and the typography with the support of the sound track, trying to create an atmosphere of predisposition in the spectator. One name marks the evolution of the credit titles from half-full of century XX to the present time: Saul Bass, the responsible for the better and most creative cinema title sequences. Graphic Design and Cinema are come together thanks to "the man of gold stroke".

\section{Key words}

Title sequence - Typography - Graphic Design - Creativity - Cinema - Saul Bass

\section{La Creatividad Gráfica en el Cine}

El papel del diseñador gráfico está yendo más allá de la elaboración del cartel y el material promocional de la película. Poco a poco, la industria cinematográfica se va dando cuenta de que los títulos de crédito no son un simple listado de nombres de actores, técnicos, productores y directores. Y la mejor manera de que el público que acude a las salas de cine sepa quiénes son esos profesionales y qué función han realizado es presentarlos de una manera creativa, atractiva y motivadora que haga que el espectador se introduzca en la película desde el primer hasta el último segundo.

Esto requiere la intervención profesional de un diseñador gráfico como experto en presentación visual y tipográfica, asesorado por un equipo de producción audiovisual, ya que tradicionalmente el campo de acción de los diseñadores ha sido la planificación de imágenes y tipos en soportes fijos como libros, revistas, periódicos, carteles, etc. La progresiva especialización de los diseñadores en soportes web y multimedia, donde tienen que trabajar tanto en el espacio como el tiempo junto al movimiento, ha facilitado que estos profesionales sean los expertos más cualificados para desarrollar con éxito los títulos de crédito.

A esto hay que añadirle su dominio en un elemento visual y textual de una gran potencia expresiva que los profesionales del cine no tienen y que, en muchas ocasiones, no recibe un tratamiento adecuado: la Tipografía. La tendencia general hasta hace unos años era plantearse los títulos de crédito en la etapa de postproducción y no desde el inicio del proyecto fílmico, dando más importancia a la imagen que al texto, sin aprovechar las relaciones creativas de ambos. Consistía simplemente en la superposición del texto sobre la imagen en los créditos iniciales y en una eterna 
lista de nombres en texto blanco sobre fondo negro en un tamaño ilegible y presentada a una velocidad que impedía su correcta lectura en los créditos finales. Esta escasa atención a la Tipografía puede provocar en algunos momentos la ilegibilidad del texto por una inadecuada elección del tipo de letra o por un incorrecto uso del color del texto con respecto a su fondo.

En la actualidad se está prestando una mayor atención en los títulos de crédito, llegando incluso a ser de mayor calidad que la propia película. Se les está dotando de funciones narrativas, más allá de la mera información de los participantes, bien a modo de resumen de la trama, bien a modo de introducción, facilitando la inmersión del espectador en el comienzo del film. También se están mejorando los créditos finales para aquellos que prefieren esperar a que terminen las aglomeraciones para abandonar la sala. Por ejemplo, con la recopilación de tomas falsas o grabaciones realizadas durante el proceso de filmación (making-off).

Los títulos de crédito se han convertido en una parte de la película de la que no podemos prescindir. Su importancia debería ser más valorada y... ¿ ¿por qué no?... sería maravilloso que hubiera una nominación en los Oscars a los mejores títulos de crédito y a los mejores carteles como reconocimiento al imprescindible trabajo de los diseñadores gráficos dentro de la industria cinematográfica. Los premios Emmy, conocidos como los “oscars de la televisión”, ya tienen un galardón a las mejores aperturas.

\section{Protagonizado por:... la Tipografía}

Como afirmábamos en el artículo “Tipo/Retórica: una aproximación a la Retórica Tipográfica”, publicado en el número 5 de ICONO 14, la Tipografía posee una gran capacidad expresiva visual que se complementa con su capacidad referencial como texto (Gamonal, 2005). El aprovechamiento de estas cualidades proporciona a los títulos de crédito una perfecta armonía y una relación creativa entre lo que estamos viendo, lo que estamos leyendo y lo que estamos oyendo.

El soporte cinematográfico multiplica las características expresivas de la letras rompiendo las barreras del estatismo y las restricciones espacio-temporales a las que ha estado sometida tradicionalmente la Tipografía. En los títulos de crédito, se convierte en la actriz principal, en la protagonista de la historia junto a la imagen fija o en movimiento: cobra vida, se personifica, adquiere cualidades humanas, baila al son de la música, se mueve por la pantalla... En definitiva, transmite sentimientos y emociones relacionados con el argumento de la película, más allá de la información que nos proporciona como texto. 
De nuevo sale a relucir la Retórica, que se manifiesta en los títulos de crédito de dos maneras:

- De forma particular, en la Tipografía se producen dos figuras retóricas como la personificación y vivificación. Por un lado, se dota a entidades abstractas como las letras de cualidades humanas y, por otro, se les confiere movimiento mediante la animación.

- De forma general, en la propia secuencia de títulos, ya que si tenemos en cuenta que toda la película es un discurso retórico, los créditos iniciales constituyen el proemio o exordio del film, es decir, su comienzo. Según Mortara Garavelli (1991: 71), “el fin del exordio era hacer que el juez o el público fuera benévolo, atento y dócil (benevolum, attentum, docilem)”. Trasladado al terreno de lo cinematográfico, los títulos de crédito iniciales tienen como función captar la atención del espectador y sorprenderle desde el primer momento, crear una actitud de predisposición hacia la película y facilitar su inmersión en la historia para que no se levante de su butaca y abandone la sala en los primeros minutos.

Del mismo modo, si consideramos la secuencia de títulos como un pequeño discurso con entidad propia y significados relacionados, pero independientes a la película que intenta persuadir a los espectadores, podemos comprobar como desarrollan sus argumentos para convencer a la manera que apuntaba Aristóteles (2002: 53):

- Lógica (logos): los títulos de crédito constituyen un mensaje persuasivo construido mediante distintos textos: imágenes, palabras y sonidos. Estos signos visuales, tipográficos y musicales procedentes de diferentes tipos de códigos y lenguajes constituyen un discurso comprensible y lógico que el espectador descifra y entiende de forma simultánea. Se convierten en una extensión lógica que apoya al film y que puede llegar a tener un significado independiente que prepara al espectador para lo que viene.

- Ética (ethos): una de sus funciones principales es acreditar y dejar constancia de todos los profesionales de todas las áreas que participan en el largometraje o cortometraje. El reconocido prestigio de algunos actores o del propio director es aprovechado como gancho publicitario para el público acuda a las salas de proyección. Muchos espectadores se basan en la reputación de algunos profesionales del mundo del cine a la hora de tomar la decisión ver una película u otra.

- Emoción (pathos): la creación de estas piezas se basa también en criterios estéticos y perceptivos cuya finalidad es motivar apelando a los sentimientos y las emociones. El 
uso del color, la confluencia de diversos códigos audiovisuales y, sobre todo, una utilización creativa del movimiento mediante la animación hacen posible que los títulos de crédito tengan una poderosa fuerza de atracción.

\section{El proceso creativo de la secuencia de títulos}

Al tratarse de un complejo mensaje audiovisual en el que confluyen texto e imágenes fijos y/o animados perfectamente sincronizados con la música, el diseño de títulos de créditos requiere de un equipo multidisciplinar para afrontar un proyecto de estas características. El plantel de profesionales está claramente dividido basándose en cada uno de los tres elementos principales mencionados:

- Diseño: los diseñadores gráficos son los expertos más cualificados para comunicar mediante la tipografía, la forma, la imagen fija o el color. Aunque actualmente se suelen hacer cargo de proyectos multimedia en los que se integra imagen en movimiento y sonido, hay que tener en cuenta que es totalmente diferente la proyección en una pantalla de ordenador a una pantalla de cine.

- Música y sonido: la música en los primeros y últimos segundos de un film es de vital importancia. Por lo tanto el creador de la banda sonora debe estar en perfecta sintonización con el equipo de responsable de los títulos de créditos. En algunas ocasiones también es necesaria la creación de efectos de sonido a cargo de un profesional.

- Animación e integración audiovisual: para dar vida a las imágenes y la tipografía es fundamental la intervención de un animador. En el caso de que se utilicen escenas específicamente rodadas para la secuencia de títulos es fundamental la implicación de un pequeño equipo de rodaje que generalmente es supervisado por el propio director de la película. Por último, con la finalidad de integrar todos los elementos (texto, imagen y sonido) se requiere un experto en montaje.

Es imprescindible la implicación del director desde los inicios del proyecto cinematográfico y no dejar los créditos para el final. Debe darle la importancia debida ya que forman parte de un todo que es el film. Históricamente los títulos de créditos no han tenido excesiva importancia para los productores cinematográficos que intentaban hacer encaje de bolillos con los presupuestos. Ante los agobios económicos, los recortes se notaban en las secuencias iniciales de muchas películas que, 
paradójicamente, eran acometidos al final del proyecto cinematográfico. Las estrategias creativas acabaron volviéndose rutinarias con el aprovechamiento repetitivo de escenas que forman parte del film o la muestra de las estrellas protagonistas con la simple superposición de rótulos.

Teniendo en cuenta esto, el proceso creativo de la secuencia de títulos debe aglutinar a un equipo multidisciplinar que tiene que trabajar unido durante todo el proyecto bajo la supervisión del director. Las diferentes fases de creación de los títulos de crédito son las siguientes:

1. Definición del mensaje: el equipo que va a crear la secuencia inicial y final del film debe reunirse con el director para que éste le transmita todo aquello que quiere expresar con su película, los objetivos que quiere cumplir, a qué público desea dirigirse... Este mensaje audiovisual que constituyen los títulos de crédito supone una síntesis y una abstracción en tan sólo unos segundos de aquello que quiere transmitir el director durante los noventa minutos que aproximadamente puede durar la película.

2. Análisis: consiste en estudiar todas las notas y reflexiones que ha manifestado el director en la reunión previa. Con la selección de las ideas más importantes se elabora un briefing que será la guía de trabajo para todo el equipo y marcar las líneas directrices del proyecto.

3. Conceptualización: en una reunión de todo el equipo creativo se comienza a proponer ideas y varias líneas de trabajo. Estas propuestas conceptuales suponen una transformación creativa de las palabras del director en imágenes y sonidos. Según estas primeras ideas, se establecen diversas líneas de trabajo, de las cuales se elegirá una para empezar a desarrollar. Una vez elegido el mensaje o concepto a transmitir se procede a establecer la división del trabajo según las especialidades. Tanto las imágenes como el sonido deben transmitir el mismo mensaje.

4. Recopilación o creación de material tipográfico, visual y sonoro: cada una de las especializaciones recopila, graba o crea su material. El diseñador gráfico comienza con el estudio de las fuentes, el color y las imágenes que va a utilizar. El responsable de la banda sonora comienza a componer la música que acompañará a las imágenes. El realizador audiovisual determinará si es necesario el rodaje de escenas específicas para la secuencia de títulos.

5. Desarrollo: con las premisas anteriormente comentadas se empieza a dar forma visual y sonora al concepto creativo que se quiere transmitir. En un principio, tiene mayor importancia hacer una propuesta visual que no contenga movimiento ni sonido. Por lo 
tanto, en estos primeros pasos, el peso del proyecto recae sobre todo en el trabajo del diseñador gráfico, sin menoscabar los otros aspectos.

6. Presentación de propuesta estática: llega el momento de que el director compruebe cómo se va desarrollando los títulos de crédito. Esta primera propuesta, como hemos dicho, se presenta a modo de storyboard, es decir, sin animación ni música. En caso de que el director no la apruebe se debe volver a empezar por el principio y revisar las propuestas que se hicieron en la reunión creativa para tomar un nuevo camino. Si la aprueba, se continúa con el proceso.

7. Animación: en este momento, el peso del proyecto se traslada a los profesionales de realización audiovisual. La propuesta estática toma vida y adquiere movimiento mediante la animación de las imágenes fijas creadas en fases anteriores. Los signos tipográficos también pueden ser animados para dar mayor expresividad a los títulos de crédito.

8. Estudios de efectos especiales y transiciones: la sucesión de imágenes necesita de una fase de montaje en la que se entrelazan mediante diversas transiciones formando el mensaje audiovisual que se quiere transmitir al público en los primeros segundos de la película. También la capacidad expresiva se puede reforzar mediante el uso de efectos especiales.

9. Integración de sonido: es la fase en la que se da voz a las imágenes. Se introducen los sonidos que se han seleccionado para acompañarlas y, por supuesto, el tema musical que va a introducir a los espectadores en la trama. La banda sonora también debe haber pasado por el visto bueno del director.

10. Sincronización: es, por así decirlo, la fase en la que se establece la coreografía entre la tipografía, las imágenes y el sonido. La sincronización también aporta valores expresivos y emocionales que refuerzan el concepto creativo. Aquí se establece en qué momento y en qué lugar de la pantalla hacen su aparición, cómo se mueven y cuándo se sucenden estos tres elementos que actúan como actores en la primera secuencia del film.

11. Presentación de propuesta animada: una vez terminado, el director tiene que ver el resultado final. En esta ocasión todos los elementos están perfectamente integrados, proporcionando el mensaje audiovisual que verán los espectadores. Si el director considera que no se ha logrado transmitir el concepto creativo, se volvería a revisar el trabajo desde la fase de animación. 
12. Grabación y montaje: si el director ha dado el visto bueno, se procede a la grabación de los títulos de crédito para posteriormente ser montado en la película.

\section{Definición mensaje}

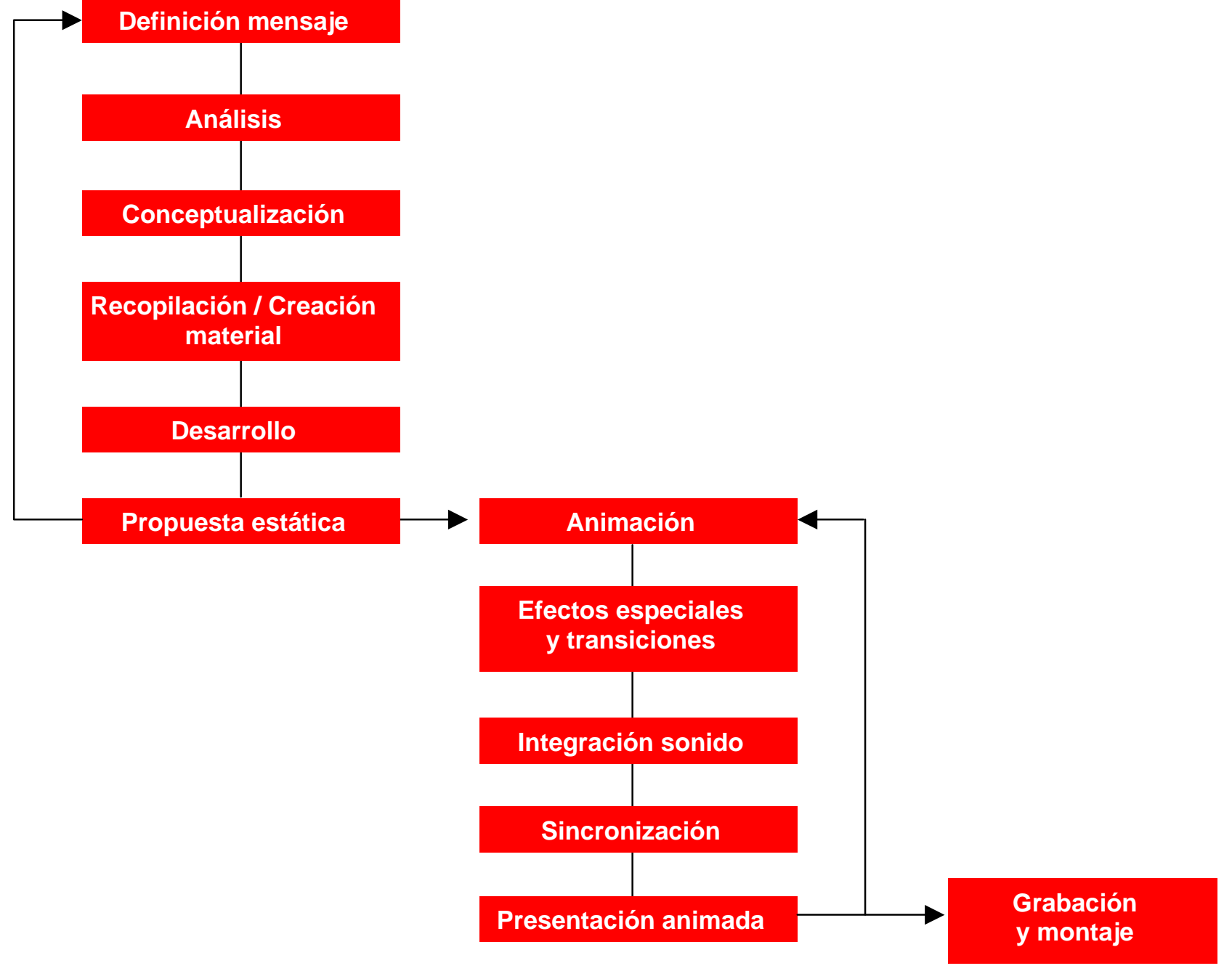

\section{De las películas de cine mudo a "Seven"}

Los inicios de los títulos de crédito y su evolución van de la mano del séptimo arte. En las primeras películas de cine mudo, los créditos eran simples carteles en los que se rotulaban a mano o mediante impresión tipográfica el título, el reparto y algunos diálogos de vital importancia para el seguimiento de la trama narrativa. Estos carteles se realizaban sobre cartulinas o tablas de color negro en las que se dibujaba las letras mediante pinceles o plumillas en color blanco para mejorar el contraste y la legibilidad del texto. Se fotografiaban y se incorporaban a la película. 
La introducción del color y el sonido en el cine no supuso una gran revolución en los títulos de crédito. Fue más determinante la aplicación de técnicas que se estaban utilizando para la Publicidad y el Diseño Gráfico. Después de varias décadas, los carteles y los títulos de crédito se basaban en el mismo concepto creativo: mostrar a las estrellas del film mediante dibujos realistas y fotografías. Como mucho, algunas secuencias de títulos incluían pequeños fragmentos de escenas importantes para después mostrar a los protagonistas con un rótulo superpuesto.

Fue precisamente un diseñador gráfico el que revolucionó todos los conceptos visuales que hasta entonces se habían aplicado en el cine. Saul Bass cambió la estética del séptimo arte presentando un diseño conceptual y simbólico de una gran fuerza semántica y metafórica que plasmaba a la perfección el espíritu del largometraje. Y se podría decir también que fue el responsable del primer proyecto de identidad corporativa para un largometraje (Meggs, 2002: 443). El director Otto Preminger contactó con él para que realizara el cartel de su película "El hombre del brazo de oro” (1955). Quedó tan encantado con la propuesta de un brazo negro, simple pero con un gran poder visual, construido mediante líneas quebradas, que le encargó también los títulos de crédito y el diseño de todo el material promocional, basándose en esa metáfora visual que reflejaba de forma inteligente la adicción a la heroína y la personalidad tormentosa del protagonista interpretado por Frank Sinatra.
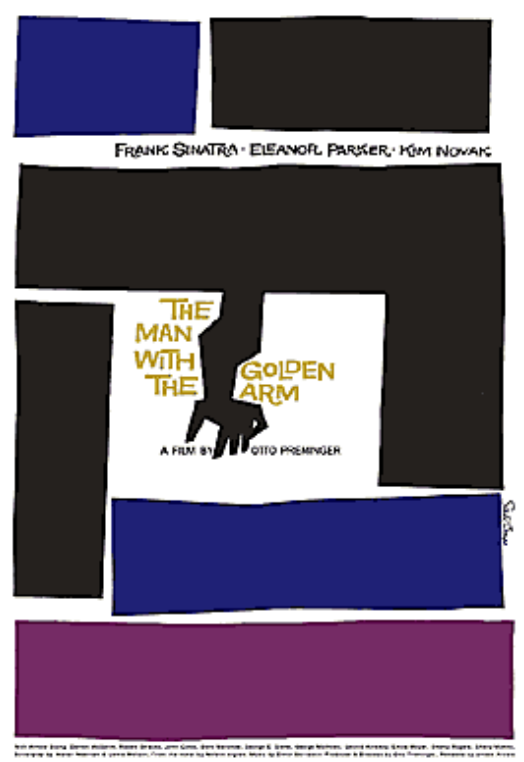

En los títulos de crédito, al ser una película en blanco y negro, Bass utiliza la fuerza del negativo. La secuencia comienza con unas simples barras blancas que se mueven por la pantalla, introduciendo los nombres del reparto, en una perfecta coreografía sincronizada con la excelente 
banda sonora de jazz realizada por Elmer Bernstein. Los ochenta segundos que dura esta secuencia concluyen con la confluencia de las barras blancas que se transforman en el icono visual que representa el film: el poderoso brazo de formas quebradas en color blanco sobre fondo negro.

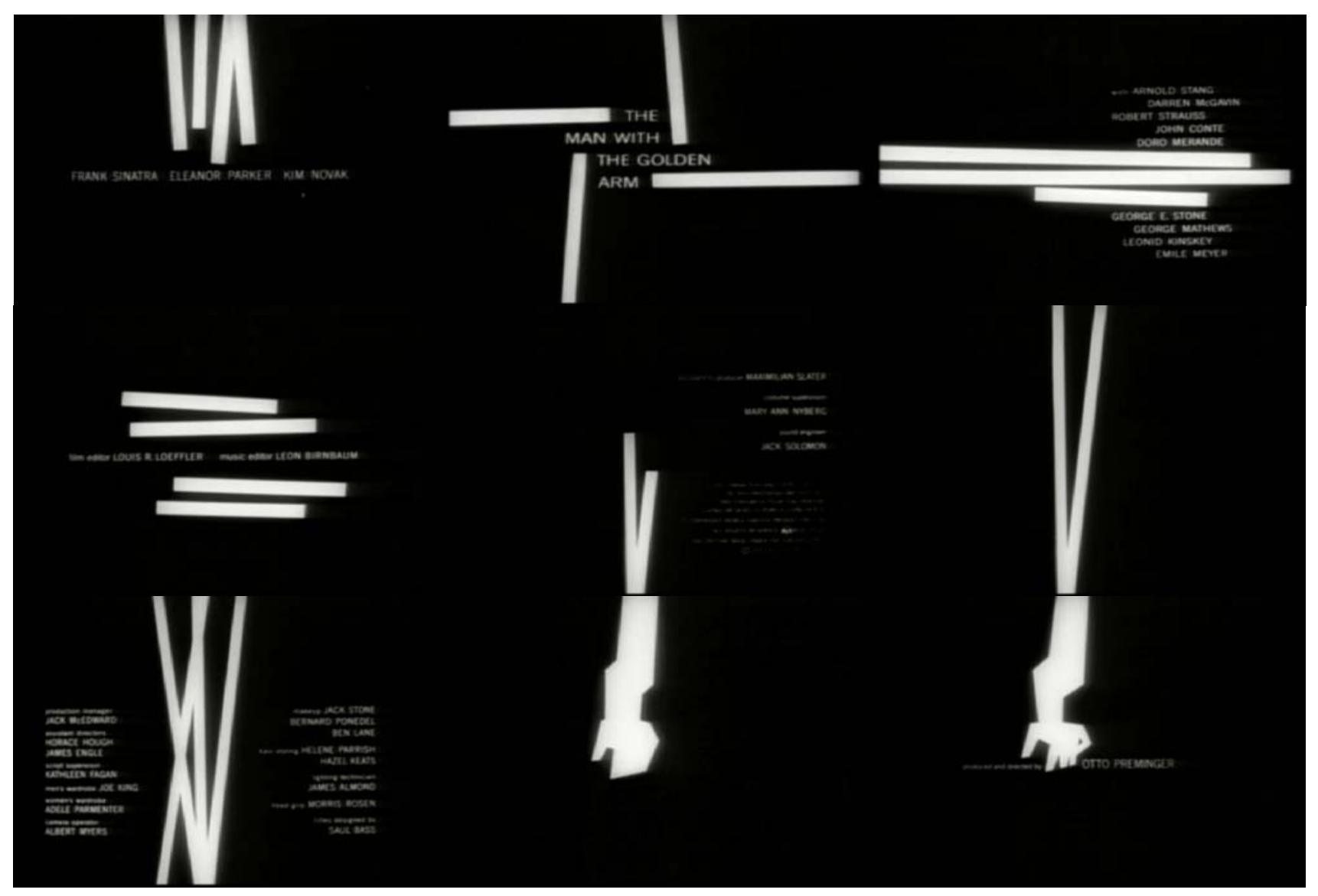

Las décadas de los 50 y 60 estuvieron copadas en este apartado por Saul Bass, pero hubo otro diseñador que no es muy conocido, pero que dejó grabada en nuestra retina una breve escena que forma parte de nuestra cultura cinematográfica: la apertura de las películas de James Bond, convertida en la seña de identidad del agente 007, en la que el espía británico más famoso dispara a quien le está siguiendo a través de la mira telescópica de un arma y la pantalla se tiñe de sangre. El autor es Maurice Binder que diseñó catorce secuencias de títulos cargadas de psicodelia y sensualidad sobre la mítica banda sonora de Monty Norman y temas musicales como los interpretados por Shirley Bassey: desde “Doctor No” (1962) hasta “Licencia para matar” (1989). Robert Brownjohn le sustituyó siguiendo su mismo estilo en “Desde Rusia con amor” y “Goldfinger”. Pero Binder no sólo trabajó para el agente 007, también tiene créditos memorables como el de "Charada". 


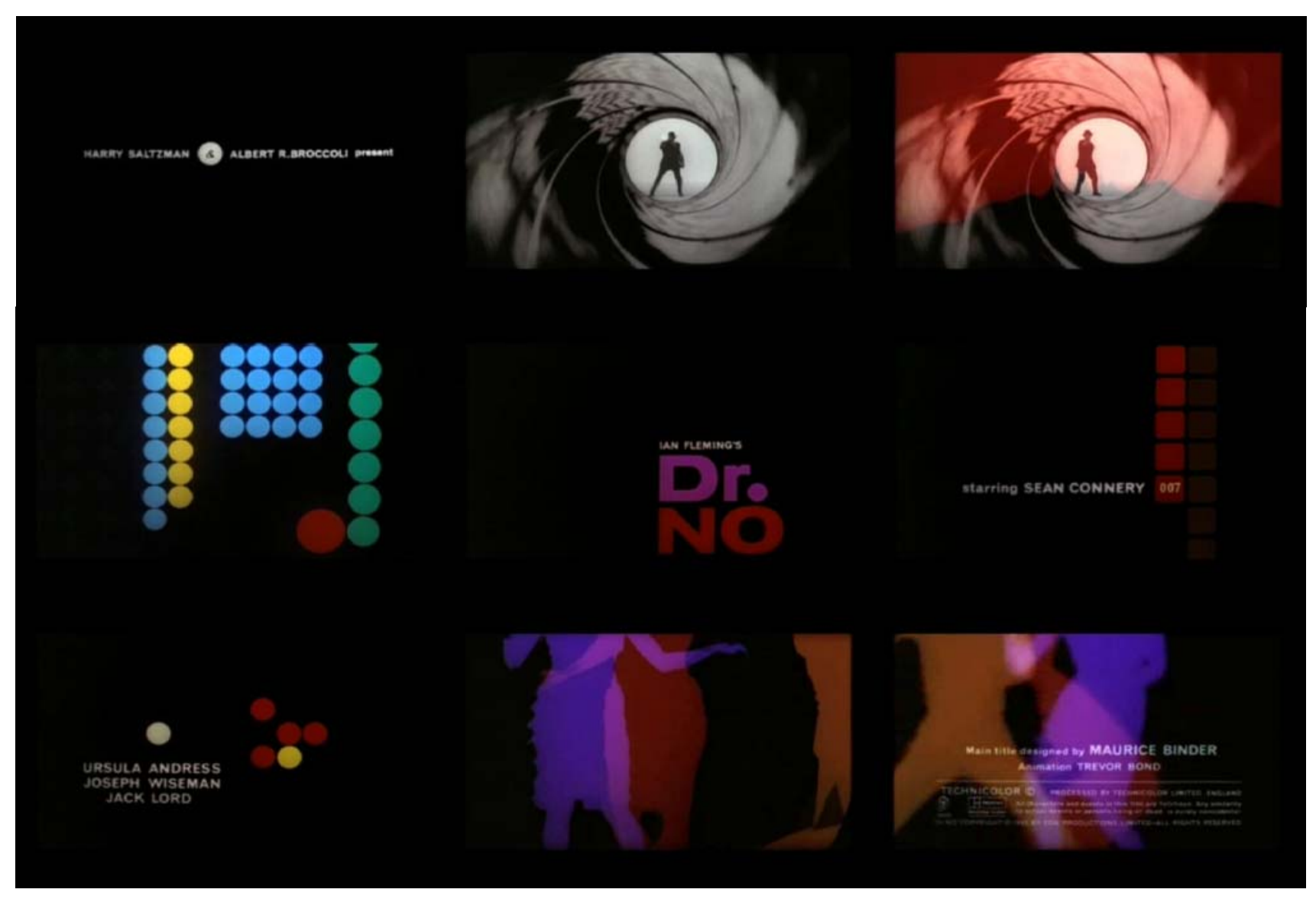

De esta época dorada quedan también para el recuerdo los fabulosos créditos realizados por De Patie y Freleng para “La pantera rosa” (1963) en la que la tipografía se mueve y actúa como un personaje más al son de la genial música de Henry Mancini. Se trata de una secuencia inicial de animación más larga de lo habitual (tres minutos y medio), pero que se hace amena por el humor con el que está realizada. El famoso diamante en cuyo interior se encuentra una imagen de un felino saltando aparece literalmente personificado en una graciosa pantera de color rosa animada. Su éxito fue tal que estos títulos de crédito fueron la base para la creación de una de las series televisivas más exitosas de dibujos animados. El personaje animado interactúa con los nombres del excepcional reparto creando situaciones hilarantes que esbozan una sonrisa en el espectador. 


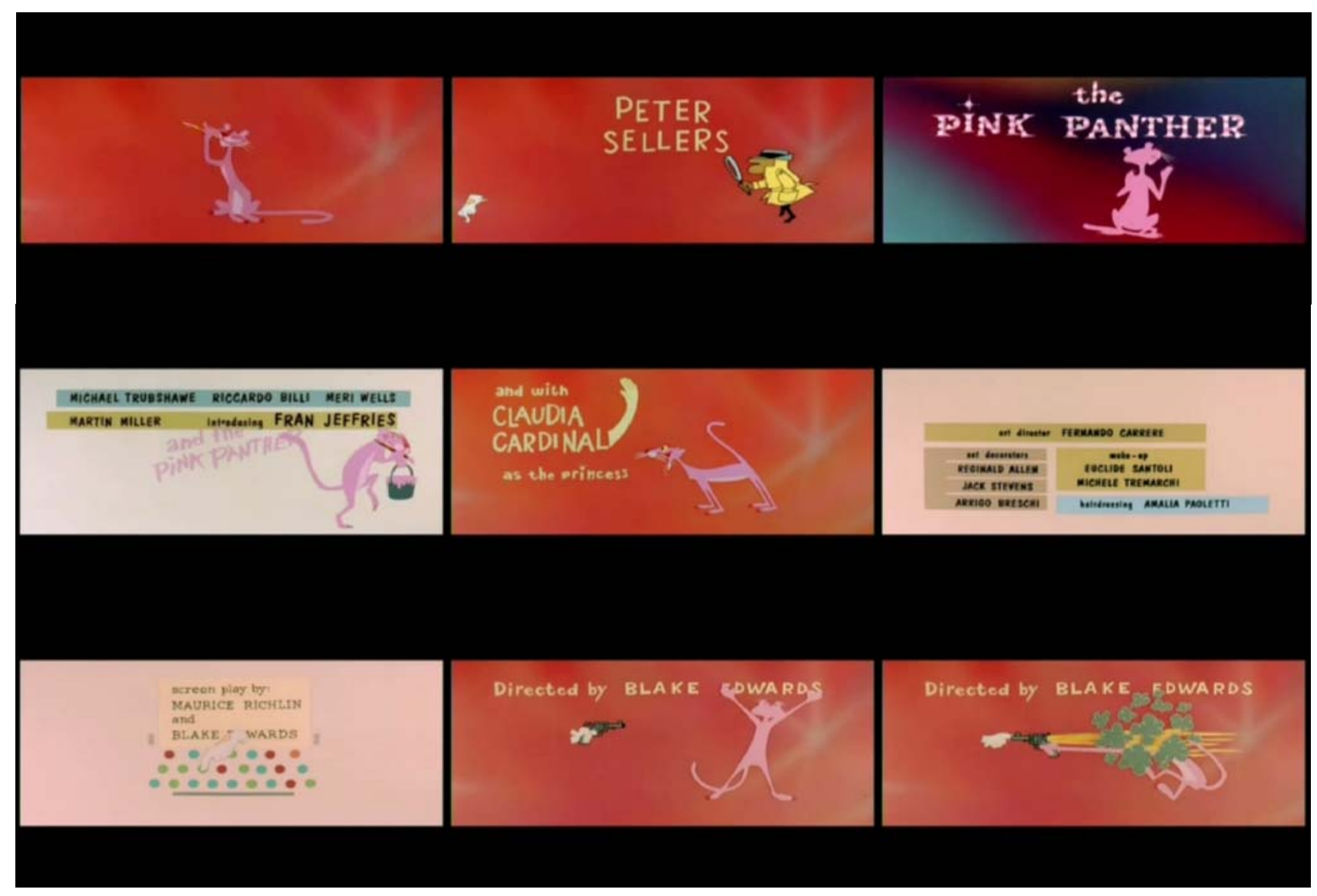

En la década de los 70 la tecnología informática llega al cine permitiendo crear los primeros efectos especiales por ordenador. Dan Perri, que realizó uno de los inicios más recordados en “La guerra de las galaxias” (1977), y Robert y Richard Greenberg, que diseñaron la apertura y los títulos de “Superman” (1978), fueron los primeros en usar la tecnología más innovadora de la época. A pesar de las facilidades que ofrecían estos nuevos recursos, los títulos de crédito de esta década y la de los 80 no tenían una calidad conceptual tan brillante como en los años anteriores. Honrosas excepciones son algunas secuencias de títulos creadas por Pablo Ferro, que se inició con Stanley Kubrick en “Teléfono rojo” (1964) y Basil Dearden en “La mujer de paja” (1964). De estos años son las mejores aperturas realizadas por el diseñador de origen cubano: “Citizen’s Band” (1977) y “Stop making sense” (1984), ambas de Jonathan Demme.

Se vuelve a recobrar el interés y la calidad de los títulos de crédito en los años 90 de la mano de Kyle Cooper con la genial secuencia de apertura de "Seven” (1997), dirigida por David Fincher, en la que se intuye la personalidad del asesino sin ser mostrado directamente. Sólo con inquietantes planos detalle y una tipografía manual realizada a base de trazos nerviosos y superpuestos. En los dos primeros minutos del film se puede ver como un personaje, que intuimos que es el maniaco que 
comete los asesinatos siguiendo los siete pecados capitales, va construyendo un macabro cuaderno con una caligrafía obsesiva e imágenes escalofriantes que recorta y pega formando una diabólica documentación de los horrores humanos. La tipografía vibra, se mueve nerviosa y cambia de iluminación compulsivamente. Esta película dejó cautivado a los espectadores desde el primer segundo. Gracias a su amplia difusión, los créditos empezaron a ser más valorados por el gran público y se comenzó a rememorar piezas antiguas que antes pasaron desapercibidas.

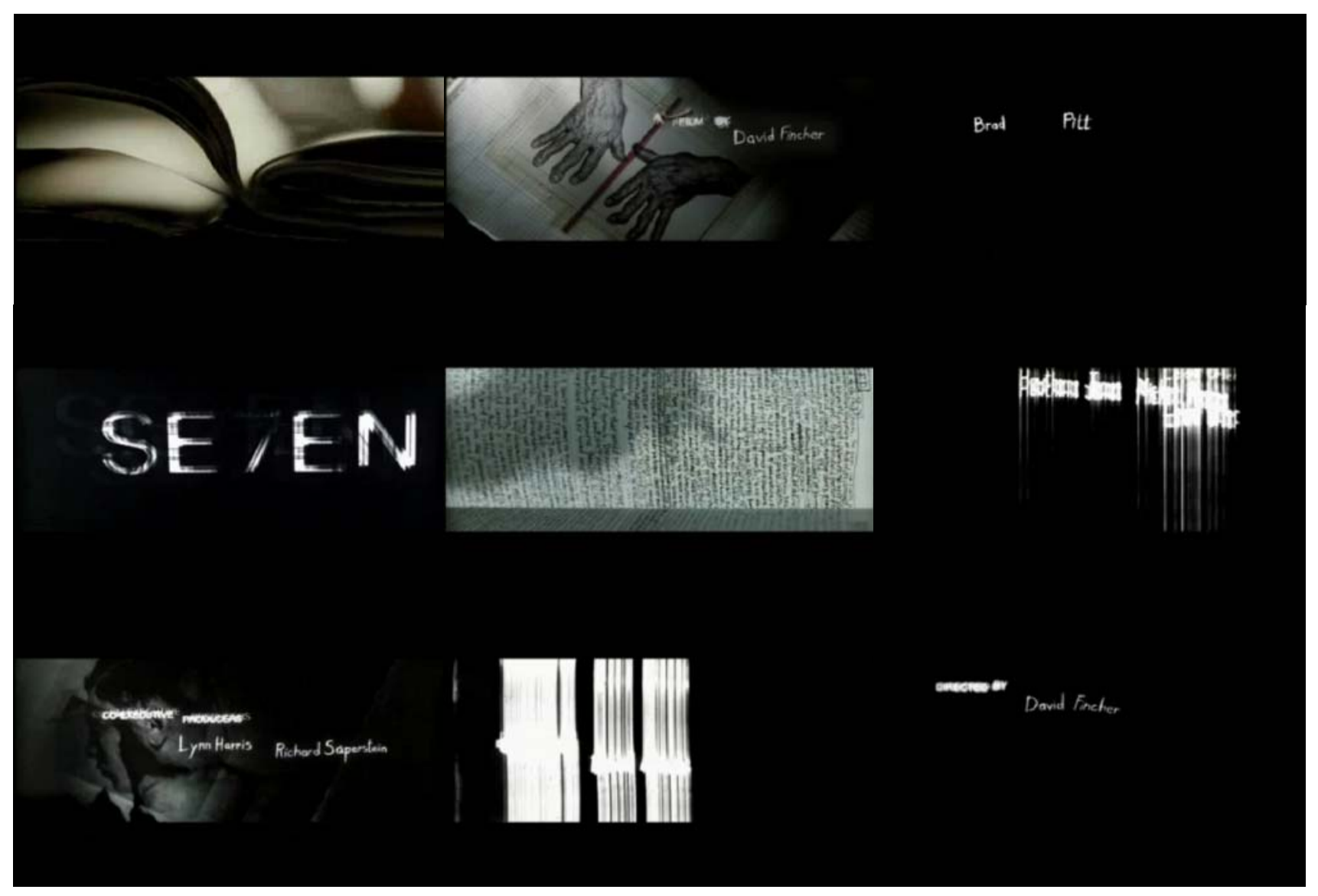

Tras este breve recorrido histórico vamos a detenernos en el que es considerado el mejor diseñador de títulos de crédito de todos los tiempos: Saul Bass. Aunque es el más importante o uno de los más conocidos, Julio Sanz $(2004,66)$ destaca otros nombres como Maurice Binder, Friz Freleng (ya comentados), Stephen Frankfurt, Arcady, Wayne Fitzgerald, Pablo Ferro (brevemente explicado, los hermanos Greenberg, Dan Perri (ya nombrados), Daniel Kleinmann, Ballsmeyer \& Everett, Garson Yu, Robert Dawson, Juan Gatti (argentino afincado en España valorado como mejor diseñador de títulos de crédito del cine español), Deborah Ross o el estudio Bureau. 


\section{Saul Bass, el hombre del trazo de oro}

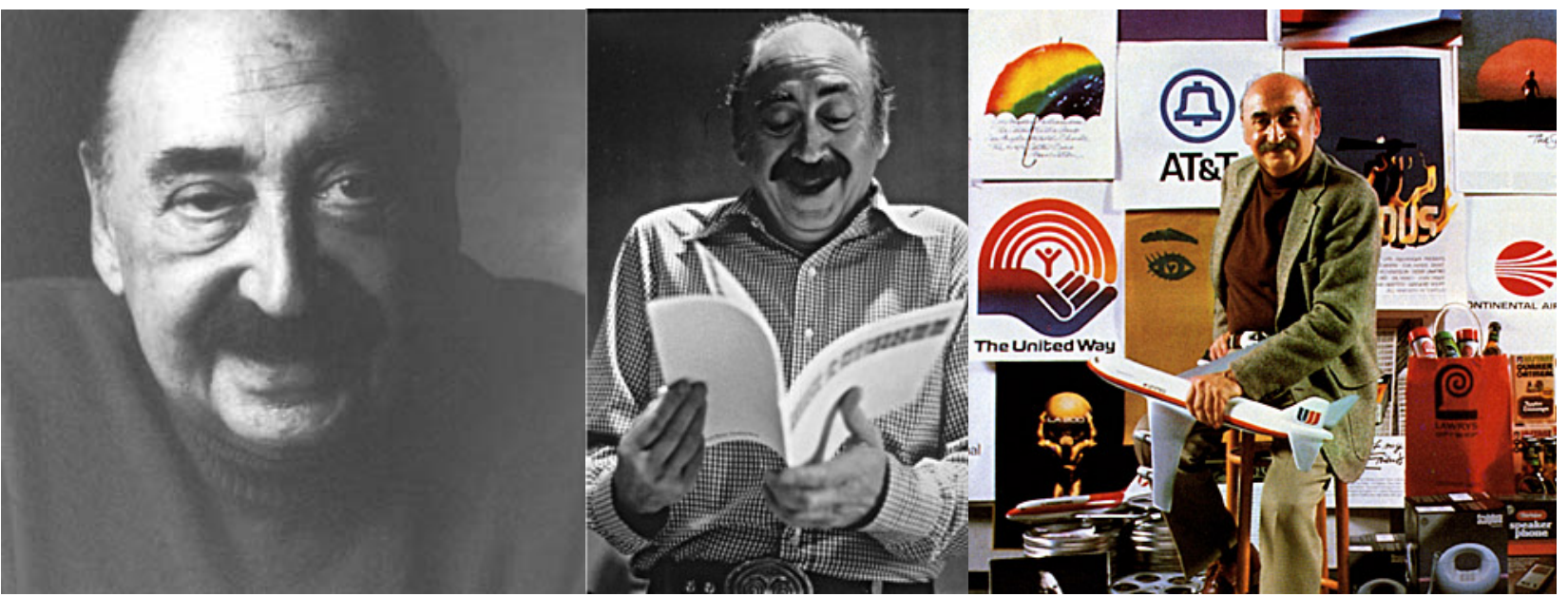

Es el gran maestro de las secuencias de títulos y también uno de los mejores cartelistas.

Su estilo revolucionó la estética gráfica del séptimo arte. Los más reputados directores de cine han solicitado sus servicios tanto para realizar carteles como los primeros minutos de sus films: Otto Preminger, Alfred Hitchcock, Billy Wilder, Stanley Kubrick, Martin Scorsese o Ridley Scott son algunos nombres dentro de su extensa carrera. Su trabajo ha servido de inspiración para muchos diseñadores actuales.
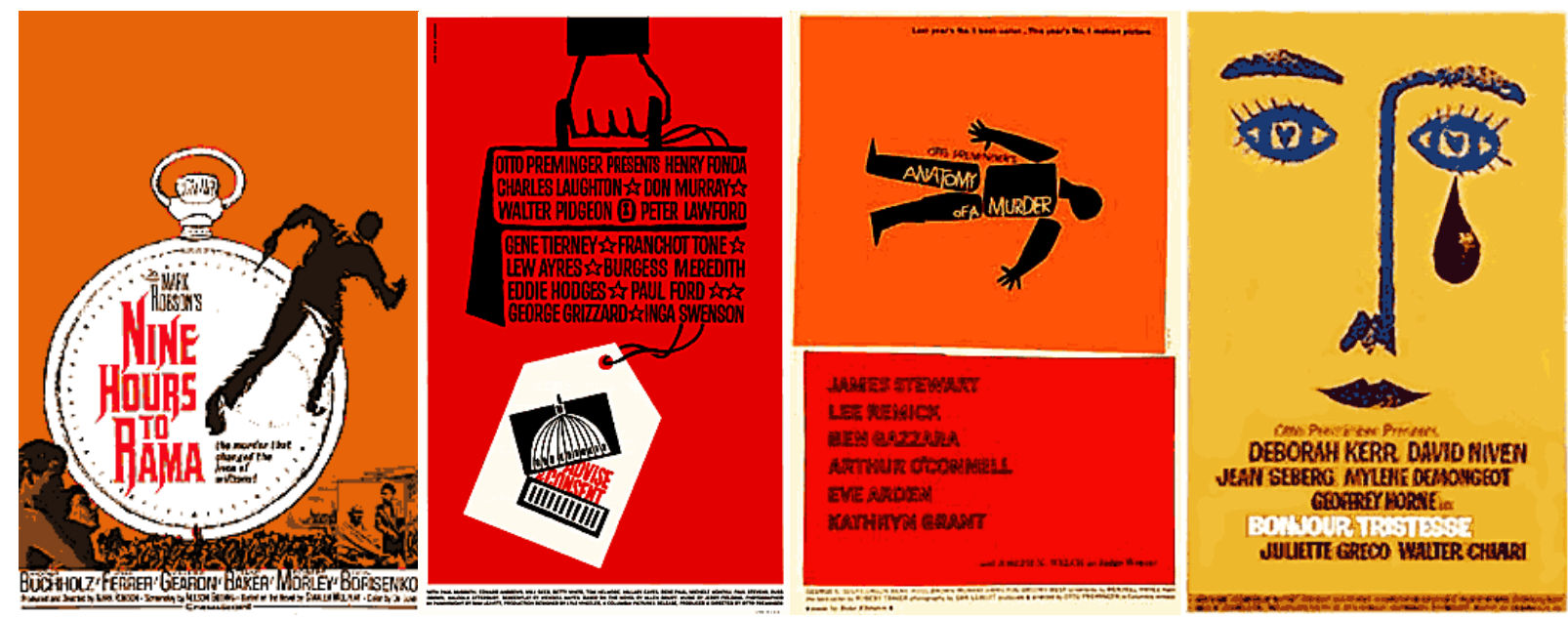


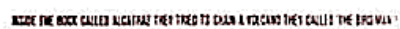

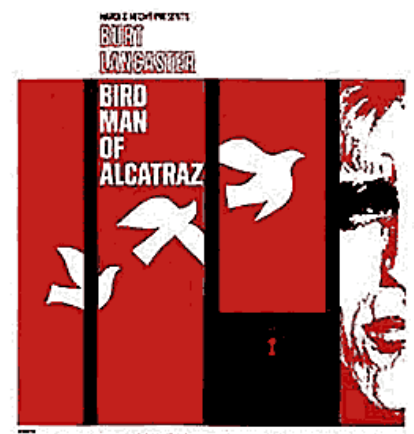

KKRRL MALOEN / THELMA RITTER / NEVLLL BRAND

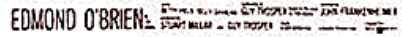
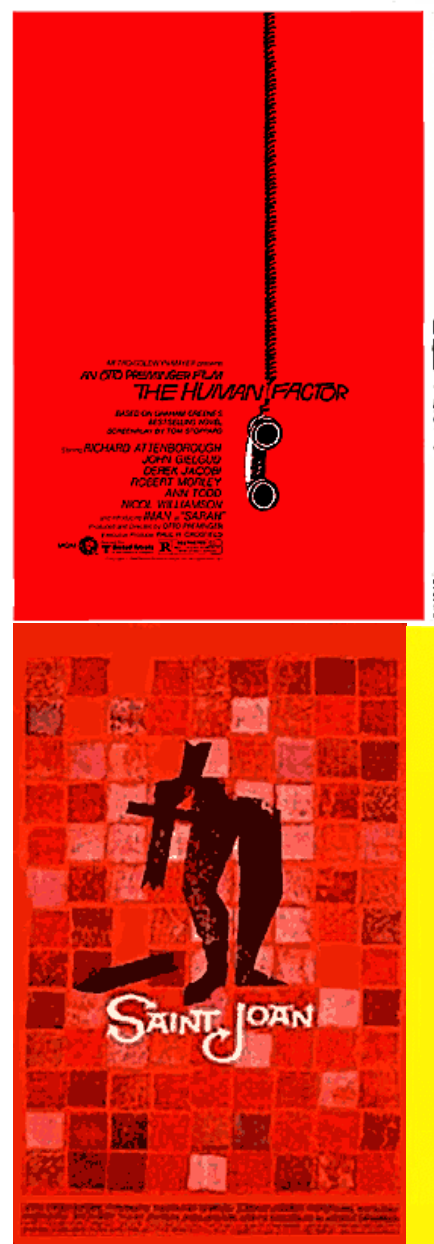
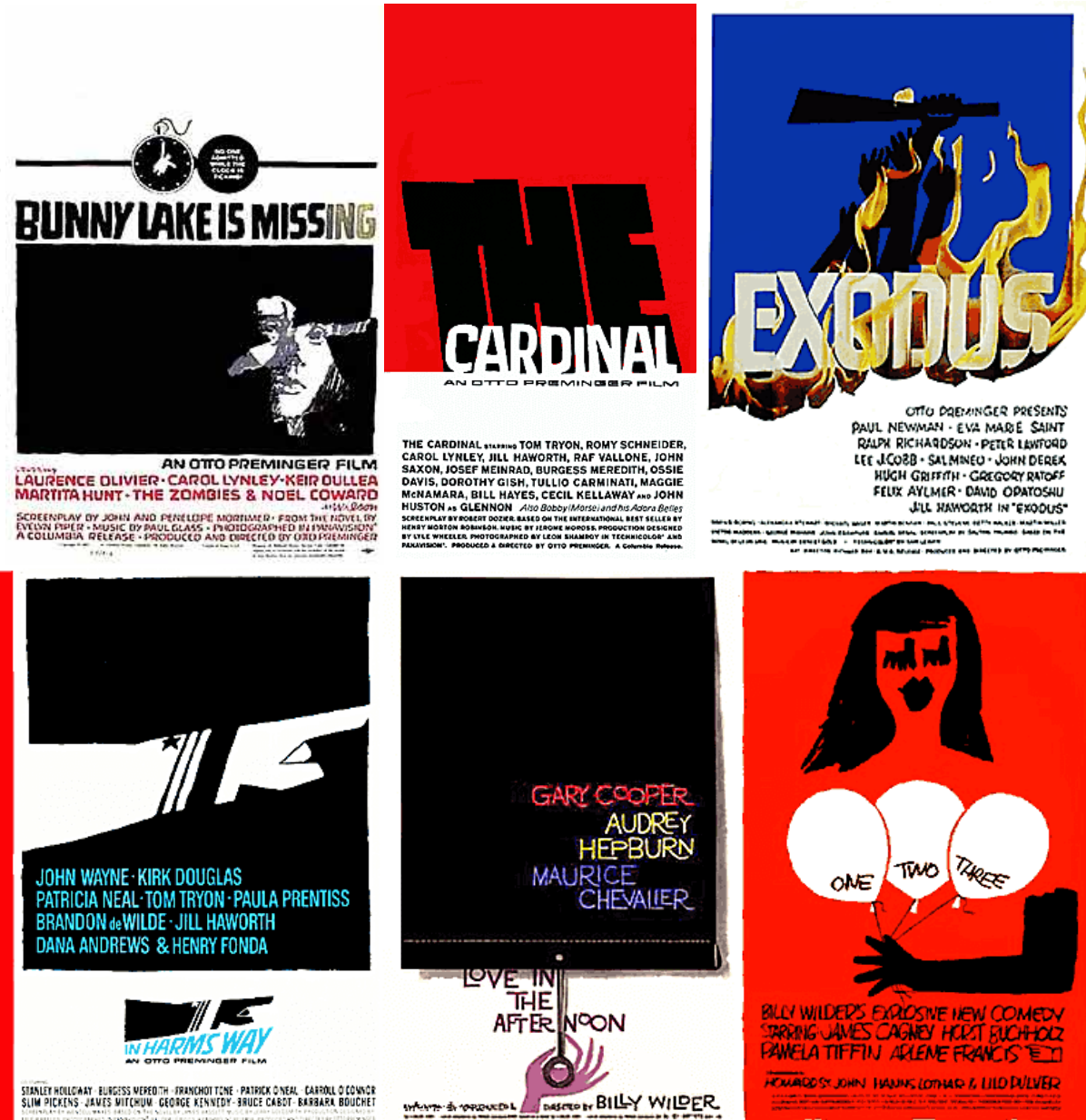

AMASTERPIECE OFMODERN HORROR

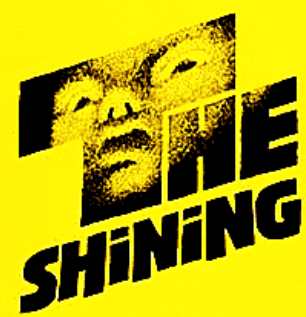

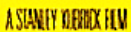

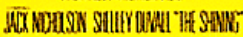

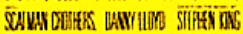

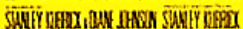

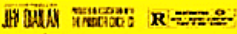

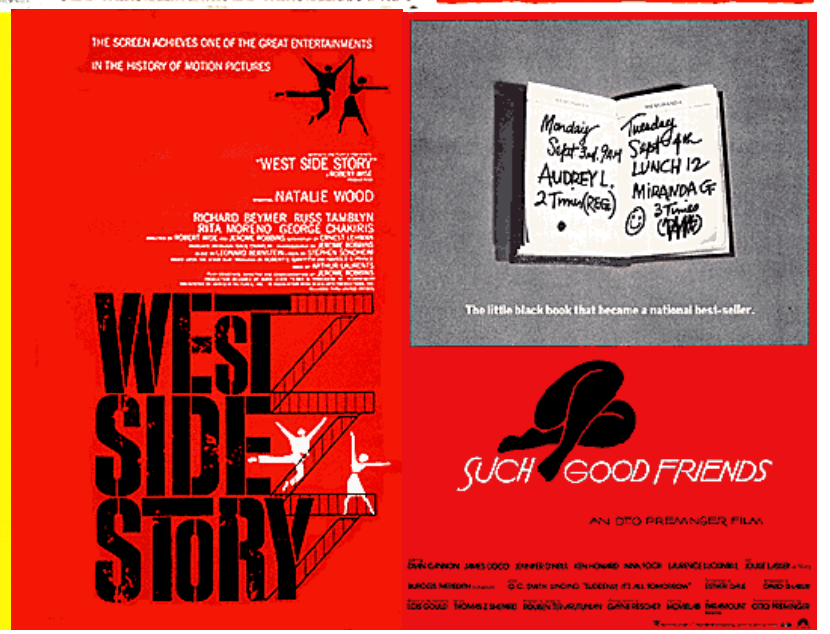

Pero no sólo es conocido por su contribución al cine. Fue uno de los mejores diseñadores gráficos norteamericanos de su época junto a Paul Rand y Milton Glaser. Meggs (2002: 443) dice de él que "redujo el diseño gráfico a una imagen dominante, sencilla, usualmente centrada en el espacio” gracias a “una habilidad extraordinaria para identificar el núcleo de un problema de 
diseño”. También afirma que “despojó al diseño gráfico estadounidense de la complejidad visual y redujo la comunicación a una imagen pictográfica sencilla”.

Su forma de trabajar es muy sencilla técnicamente, pero compleja semánticamente:

- Construye formas orgánicas sencillas mediante recortes abruptos y simples de cartulina mediante tijeras o trazadas con un pincel.

- Estas formas transmiten una gran energía visual ya que están dibujadas con total libertad sin someterse a la rigidez de la geometría exacta.

- Utiliza tipografía dibujada manualmente que a veces combina con letras de imprenta.

En una entrevista el diseñador habla abiertamente de su particular concepto de la creatividad (Bass, 1989: 13-15): “es la noción de tomar algo ‘conocido’, aun algo trillado, y tratarlo de tal manera que se transforma en una experiencia completamente fresca. Algo así como transformar lo común y corriente en extraordinario”. Destaca la importancia de definir correctamente el problema o la necesidad comunicativa y recomienda dedicarle una gran cantidad de tiempo antes de encarar un nuevo proyecto. Tras esta primera fase, procede a la traslación del problema a un concepto creativo basado en una imagen, “en una frase visual que sea más de lo que parece a simple vista, o que en cierta forma sea diferente de lo que parece en una primera impresión”. Para traducir el briefing al diseño, Bass utiliza medios que nos remiten a la Retórica: “la ambigüedad y la metáfora suelen ser centrales en mi trabajo, y por cierto en el trabajo de la mayoría de los cineastas y diseñadores que admiro”. Usa estas estrategias retóricas porque considera que el estilo indirecto es a la vez práctico y estético: "Las cosas que son lo que aparentan cumplen su función y pronto se vuelven tediosas. Lo ambiguo es intrínsicamente más interesante, más desafiante, más inclusivo, más misterioso y más potente. Obliga a volver a examinar, agrega tensión, otorga vida; y debido a que hay más que descubrir, tiene mayor longevidad”.

Rechaza categóricamente la idea de una creatividad gráfica fruto de una inspiración casi mágica. El proceso creativo es un camino que puede hacerse largo y duro, pero que siempre conduce a una buena idea. Ante el desconocimiento del proceso, los jóvenes diseñadores y estudiantes ven productos ya finalizados de los que quedan maravillados sin conocer su construcción. Considera que esto les puede llevar a "tener la ilusión de que estas cosas realmente surgen espontáneamente de la cabeza de algún diseñador”. El tortuoso camino hacia un gran concepto creativo es igual tanto para los diseñadores experimentados como los primerizos, la única diferencia es que los primeros "tienen menos ansiedad frente al proceso porque sabe que finalmente llegará a donde apunta”. 
Reconoce que estos falsos mitos a veces son alimentados por los propios diseñadores con afirmaciones tan poco racionales como: "Bueno, estaba en un restaurante y garabateé esto en la servilleta...”, “Me estaba afeitando...”, “Estaba en el avión...” o “Iba en el taxi...”. Bass es indulgente con estos profesionales y afirma que "no lo hacen con maldad, es que realmente les gustaría creer que las cosas sucedieron de esa manera”.

Esta filosofía sobre la profesión del diseño y la creatividad se debe a una sólida formación en el Brooklyn College de su Nueva York natal. Entre sus profesores se encontraba Gyorgy Kepes, uno de los principales teóricos de los últimos años de la Bauhaus que emigró a Estados Unidos tras el fin de la escuela alemana. La influencia de su tutor se deja entrever en sus trabajos posteriores llenos de conceptualismo y abstracción basados en una síntesis de los mensajes visuales con los menores recursos gráficos posibles.

Tras su graduación, trabajó en varias agencias de publicidad neoyorkinas hasta que se muda a Los Ángeles, la meca del cine. Este hecho cambia totalmente su vida. Es contratado por la productora Warner para realizar carteles de largometrajes dentro de su departamento de publicidad. Desde entonces casi todos sus proyectos empiezan a estar relacionados con el cine y se enamora del séptimo arte. En 1952 funda su propio estudio de diseño con varios socios donde compagina los proyectos cinematográficos con trabajos publicitarios y de identidad corporativa para las más importantes compañías norteamericanas.

El encargo de sus primeros títulos de crédito le llega de la mano del director austriaco Preminger para el musical “Carmen Jones” (1954) para el que trabajó en diez largometrajes más. Uno de sus trabajos más conocidos e imitados es la secuencia de apertura de “Anatomía de un asesinato” (1959). Con un concepto visual simple, pero impactante, basado en la silueta de un cadáver, Bass establece uno de los mejores preludios del cine. La secuencia inicial se abre con la formación del cadáver mediante las diferentes piezas que lo conforman a la manera de un puzzle. Con la figura ya completada se presenta el título del film para posteriormente introducir el reparto de actores y demás participantes mediante las diversas partes del cadáver (brazos, piernas, tronco y cabeza) al ritmo de la música de Duke Ellington. 


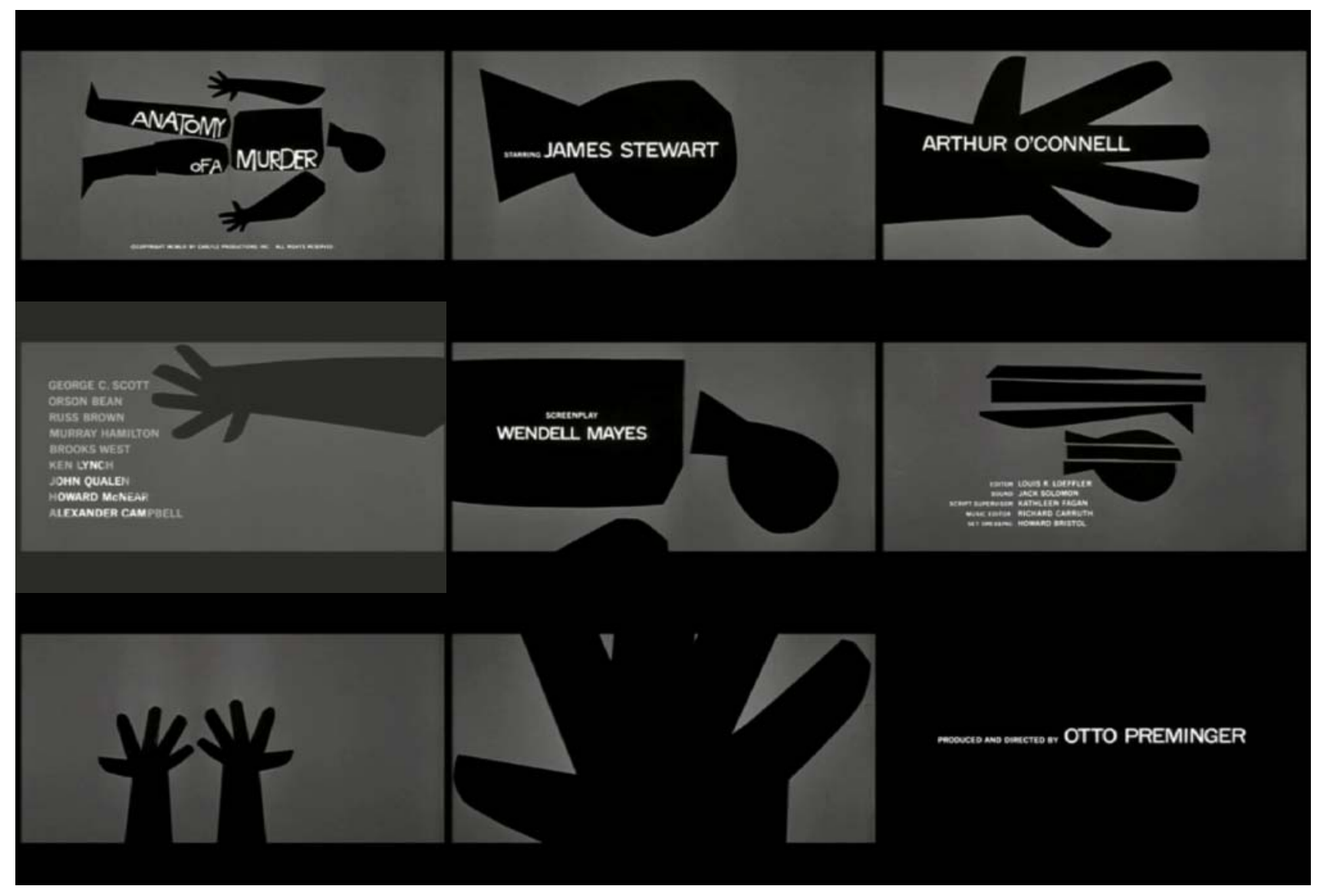

Alfred Hitchcock quedó prendado con estos títulos de crédito y los de “El hombre del brazo de oro” (comentados anteriormente) y solicitó su colaboración. Fruto de la unión de estos dos grandes genios, surgieron un cartel y una secuencia de apertura que pasó a la historia. "Vértigo" (1958) es uno de los trabajos más relevantes de Bass. Para reflejar visualmente el mal de las alturas que sufre Scottie, el personaje protagonizado por James Stewart, utiliza diversas espirales en movimientos circulares para plasmar la sensación inquietante del vértigo y el carácter onírico que subyace en el film. La secuencia abre con un plano detalle de la parte inferior izquierda del rostro de la protagonista Madelaine, interpretada por Kim Novak. La música de Bernard Herrmann es ideal para crear esa atmósfera intrigante. La imagen nos muestra un rostro que no podemos reconocer creándose un ambiente de misterio en torno a la figura femenina, acentuado por una iluminación débil. Después la cámara se desplaza a la izquierda y se acerca a los labios, un claro objeto de deseo. Seguidamente aparece el nombre del protagonista masculino desde la parte inferior hasta situarse por encima de los labios de la mujer. La tipografía elegida por Bass es una Clarendon, una letra con remates cuadrados, en mayúsculas y hueca, cuyo contorno interior deja ver las imágenes de fondo. El nombre desaparece mediante un fundido y la cámara continúa su viaje enigmático por el rostro de 
la mujer subiendo hasta un plano detalle de unos ojos inquietantes que miran a los dos lados. Esta vez, el nombre de la actriz protagonista entra en la pantalla desde arriba para situarse debajo de los ojos. De nuevo el texto se desvanece mediante fundido y la cámara se desplaza hacia el ojo derecho de la mujer. El nombre del director entra en la pantalla desde el centro y se para debajo del ojo, un símbolo que representa a la perfección la función de Hitchcock. El objetivo vuelve acercarse más aún a su ojo mientras cambia la iluminación volviéndose más oscura y virándose la pantalla a color rojo, representando la sangre y la violencia. El ojo se abre aún más y de su pupila comienza a salir el título de la película y desaparece de la pantalla por la parte superior. También de la pupila surge una espiral de color morado que gira acercándose hacia al espectador como en un intento de hipnotizarle o marearle para que comparta la sensación de vértigo. La imagen de la mujer se funde a negro y comienza la aproximación inquietante de varias espirales de diversos colores acompañadas por los nombres del resto del reparto. Cada espiral se va enlazando mediante fundidos. En la última, entra de nuevo la imagen del ojo virada a rojo y desde la pupila sale el texto “dirigido por: Alfred Hithcock” para terminar fundiéndose a negro.

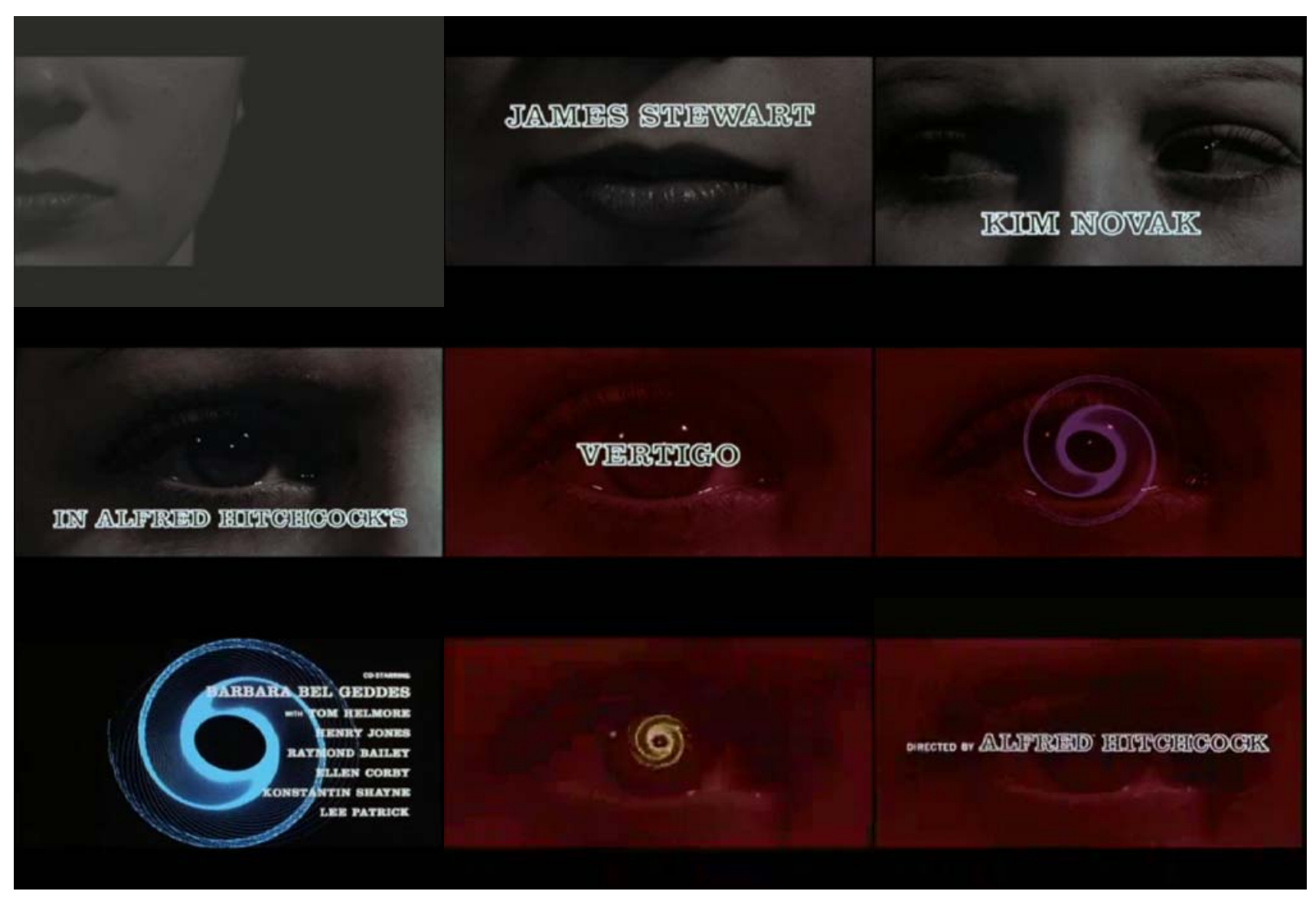


El cartel de "Vértigo” es un ejercicio de síntesis gráfica característica de Bass. Dos siluetas, una masculina en masa de color negro y otra femenina hueca a línea, que se precipitan al vacío dando la sensación de girar de forma vertiginosa, a pesar del estatismo del soporte bidimensional, gracias a una espiral blanca. La tipografía, en este caso, está dibujada a mano en color negro sobre un fondo rojo.

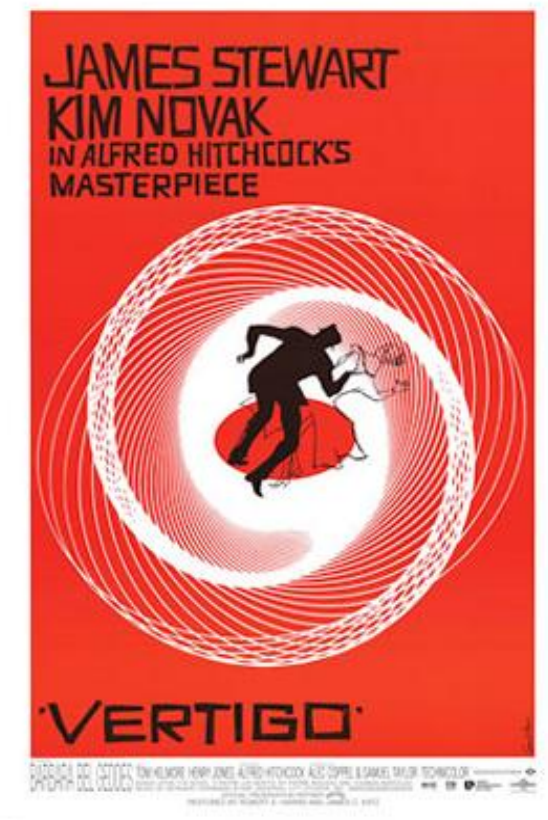

La colaboración continuó con los créditos del largometraje “Con la muerte en los talones” (1959). Los 120 segundos que dura esta secuencia nos muestra el ritmo frenético de una ciudad comenzando con la formación animada de una retícula en perspectiva formada por líneas blancas verticales y horizontales sobre un fondo de color verde. Los nombres de los actores principales suben y bajan como si estuvieran en un ascensor. Tras la aparición del título del film, el fondo verde desaparece mediante fundido mostrándose la estructura de un edificio con cristaleras que coincide con la retícula creada por las líneas. A través de los cristales podemos ver el frenesí del tráfico de una ciudad mientras ascienden y descienden los nombres de actores secundarios y otros participantes. De nuevo, con un fundido se nos muestra la incesante entrada y salida de personas por las puertas giratorias de un edificio. La secuencia finaliza con varias tomas que se enlazan por corte: el trasiego de transeúntes entrando en el metro, el cruce de un semáforo, el ir y venir por unas escaleras, la pelea de dos mujeres por un taxi y la pérdida de un autobús cuya puerta se le cierra en las narices a un hombre, que precisamente es Hitchcock en uno de sus particulares cameos. 


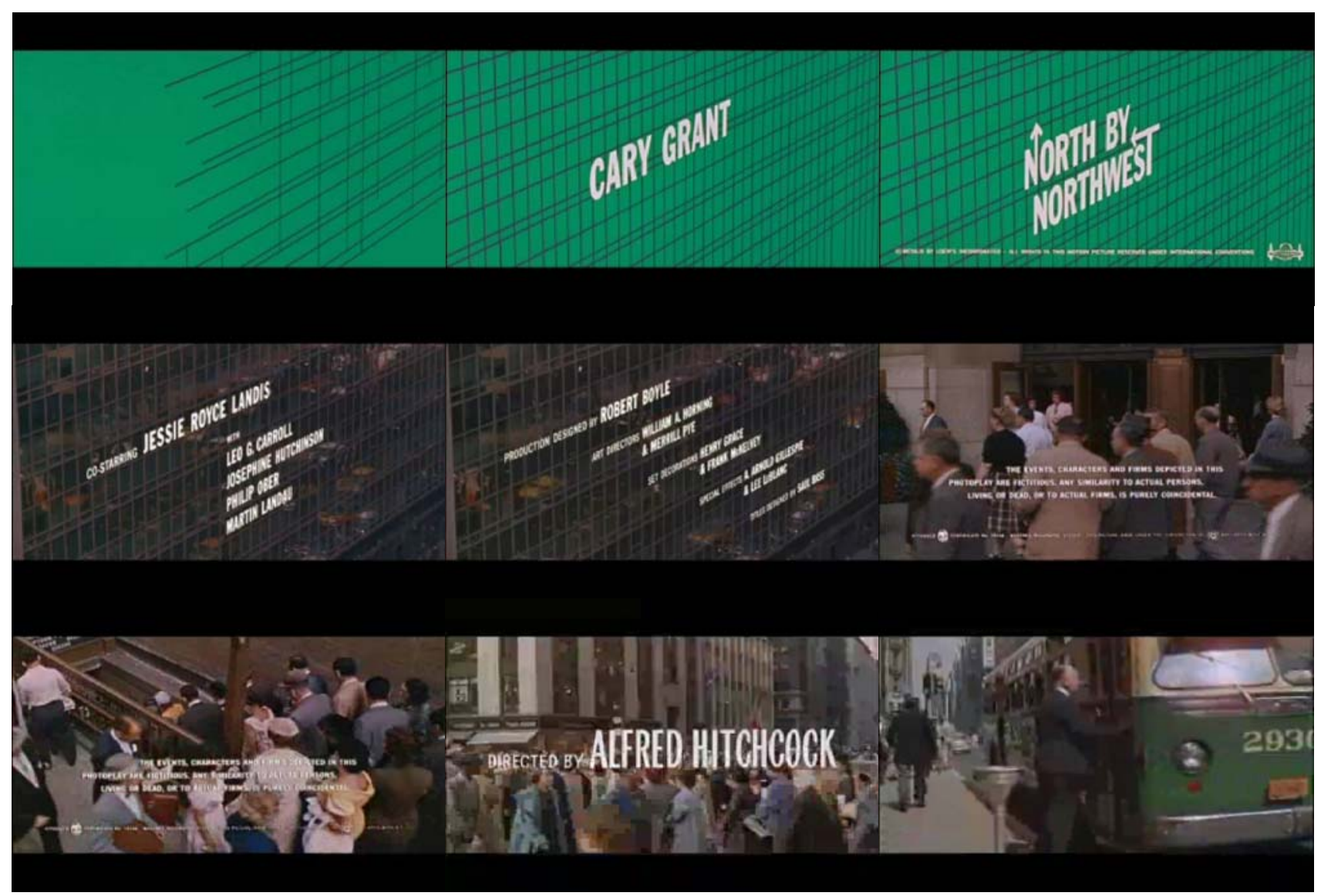

Trabajarán juntos una vez más en “Psicosis” (1960). Aunque no diseñó el cartel, sí realizó el storyboard para este largometraje, incluida la conocida secuencia de la ducha, de la que se dice que fue él quien la dirigió y no Hitchcock. Esto generó polémica ya que el director británico afirmó que la dirigió personalmente y el diseñador insistió en que él fue el responsable de su rodaje. Tras este enfrentamiento no volvieron a trabajar juntos. En la secuencia de títulos, Bass recurrió de nuevo a formas lineales blancas sobre fondo negro cuyo frenético movimiento se sincronizaba con la chirriante banda sonora creada de nuevo por Herrmann. Las líneas atraviesan de manera acelerada la pantalla horizontal y verticalmente introduciendo los nombres del reparto. La fragmentación de algunos textos clave como el título de la película y los nombres del director y los actores protagonistas reflejan el carácter psicótico de Norman Bates, el personaje protagonizado por Anthony Perkins. 


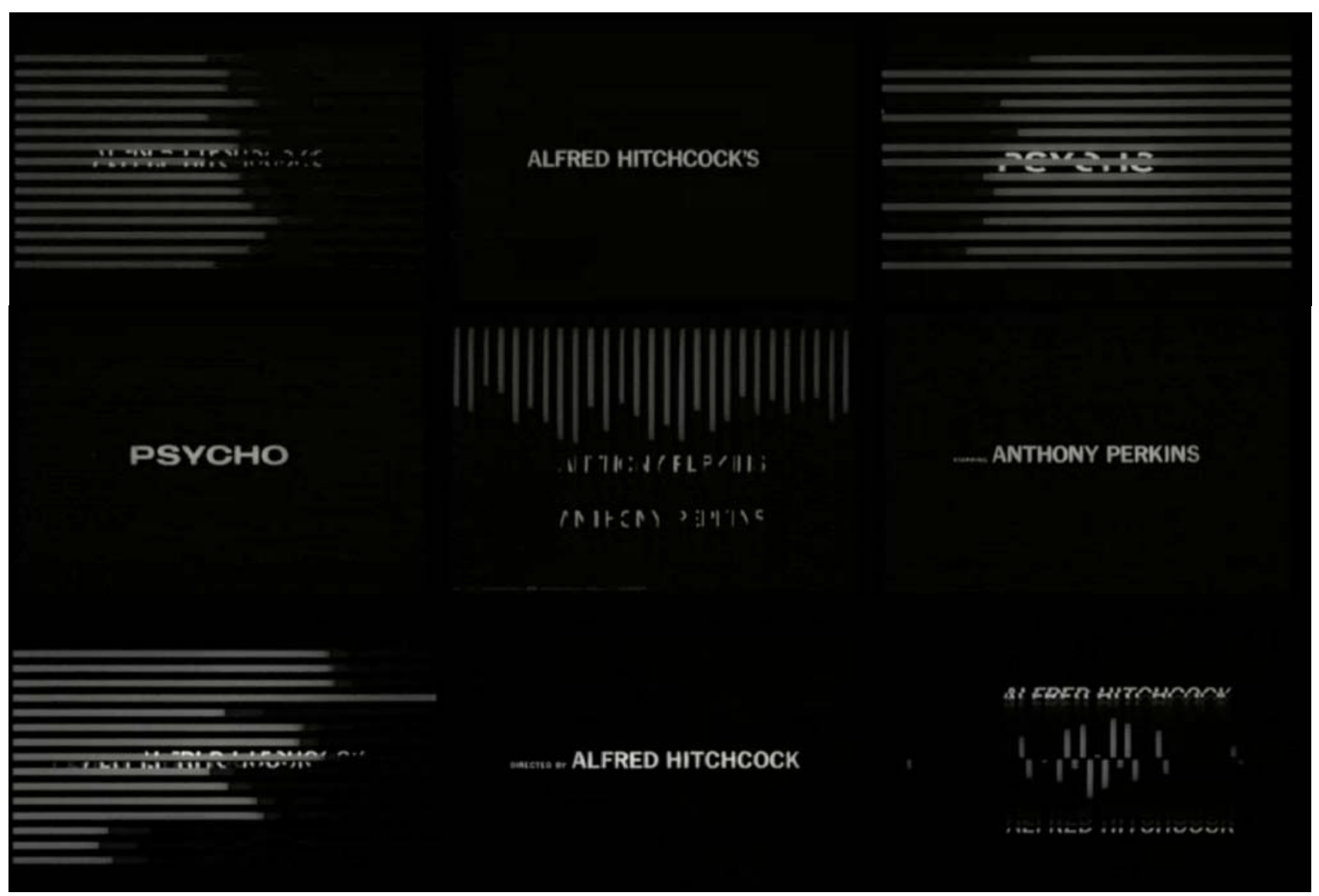

Aunque sigue realizando títulos de crédito memorables como los de "Espartaco” (Stanley Kubrick, 1960), “Éxodo” (Otto Preminger, 1960) “West Side Store” (Jerome Robbins y Robert Wise, 1961) o “Extraña amistad” (Otto Preminger, 1971) durante la década de los 60 y 70, comienza a centrarse en la realización cinematográfica junto a su segunda esposa Elaine. Se trata de una faceta poco conocida, pero el diseñador llegó a conseguir un Oscar en 1968 al mejor cortometraje por “Why man creates”, una apología audiovisual de la creatividad humana. Dirigió otros cortos titulados “The searching eye” (1964), "From here to there” (1964), "Notes on the popular arts” (1976), “The solar film” (1980) y “Quest” (1983). En 1974 estrena su primer y único largometraje “Encuentros en la IV Fase”, una película de ciencia-ficción en la que nos muestra un mundo dominado por los hormigas. También produjo un documental titulado “Bass on the titles” (1977) en el que se analiza su trabajo como responsable de las mejores primeras secuencias de mundo del cine.

Tras su aventura como director entre 1970 y 1990, sin el éxito que él mismo esperaba, se centra en encargos comerciales relacionados con la publicidad y la identidad corporativa para compañías privadas y reduce sus encargos para diseñar títulos de crédito. Bass creó numerosos logotipos para empresas como AT\&T, Bell Systems, United Airlines, Alcoa, Minolta, Warner 
Comunications, Security Pacific Bank, Quaker Foods \& Beverages, Exxon, Paul Harris Stores, Fuller Paints, Frontier Airlines, Continental Airlines o Avery International. De esta época son las secuencias iniciales de “Alien, el octavo pasajero” (Ridley Scott, 1979), “Al filo de la noticia” (James L. Brooks, 1987), “Big” (Penny Marshall, 1988) y “La guerra de los Rose” (Danny de Vito, 1989). Estos trabajos quizá no llegan a la excelencia a la que nos tiene acostumbrado.

En los 90, Martin Scorsese le llama para que realice los créditos de "Uno de los nuestros" (1990) junto a Elaine. La sintonía entre los tres es perfecta y su colaboración continúa con "El cabo del miedo” (1991), “La edad de la inocencia” (1993) y “Casino” (1995), la última secuencia de títulos que dejó para el recuerdo antes de su fallecimiento en 1996. En sus últimos años de vida, también se encargó del diseño de los carteles de la ceremonia de los Oscars.

Toda una vida dedicada a sus dos grandes pasiones: el Diseño Gráfico y el Cine.

\section{Conclusión}

Los títulos de crédito son pequeñas piezas audiovisuales que contienen un marcado carácter persuasivo y, a la vez, creativo. Debido a la vital importancia que tienen los primeros instantes de una película en el ánimo del espectador, la secuencia de títulos requiere de una planificación y un proceso en el que interviene un equipo multidisciplinar comandado por un diseñador gráfico profesional y supervisado desde el primer momento por el director del film. Los integrantes de este grupo son los encargados de engarzar con una perfecta sincronización los elementos que conforman los títulos de crédito (texto, imagen y sonido) dentro del formato de la pantalla, jugando con los factores del espacio, el movimiento y el tiempo.

Un comienzo original y creativo logra meterse al público en el bolsillo, crear un estado de disposición favorable hacia la película, si consigue impactar en los segundos iniciales. Si el principio es importante, también lo es el final. La película no acaba con el rótulo de FIN. Los créditos iniciales nos muestran los participantes más relevantes del film (actores protagonistas, director de fotografía, productor, guionista, etc), pero también intervienen una gran cantidad de profesionales de carácter más técnico que pasan inadvertidos para los espectadores ya que se presentan de una forma que resulta aburrida. Más allá de dejar una mera constancia de su participación, los créditos finales también deben ser tratados de una manera más creativa.

Cada vez se están cuidando más estos aspectos. Por eso, permítanme una sugerencia: lleguen puntuales al cine y fíjense bien en los títulos de crédito. No se levanten de sus butacas hasta que 
cierren las cortinas de la pantalla. Además de evitar las aglomeraciones de salida, puede que se lleven una grata sorpresa.

\section{Bibliografía}

- ARISTÓTELES (1990): Retórica, Gredos, Madrid.

- BASS, Saul (1989): “Transformando lo ordinario” en VV.AA (2001): Ensayos sobre Diseño. Diseñadores influyentes de la AGI, Ediciones Infinito, Buenos Aires, pp. 13-15.

- BERTRAN, Xavi (2005), recopilador: “Títulos de crédito” en www.titulosdecredito.org, consultado el 3-11-2005.

- BROWN, David R. (1982): “Saul Bass” en http://www.aiga.org/content.cfm?contentalias=saulbass, consultado el 3-11-2005.

- BELLANTONI, Jeff y WOOLMAN, Matt (1990): Tipos en movimiento. Diseñando en el Tiempo y el Espacio, Index Book, Barcelona.

- COSTA, Joan (2003): Diseñar para los ojos, La Paz (Bolivia), Grupo Editorial Design.

- COUNTS, James (2005): “Just the beginning: the art of film titles” en http://www.twenty4.co.uk/03-articles/Art\%20of\%20Fim\%20Titles/main.htm consultado el 3-112005.

- GAMONAL ARROYO, Roberto (2005): Tipo/Retórica: una aproximación a la Retórica Tipográfica en ICONO 14 n 5, Madrid, http://www.icono14.net/revista/num5/articulo6.htm consultado el 3-11-2005.

(2004): David Carson contra Aristóteles: un análisis retórico del Diseño Gráfico en Razón y Palabra n 37, México, www.razonypalabra.org.mx/anteriores/n37/rgamonal.html consultado el 3-11-2005

- MEGGS, Philip (2002): Historia del Diseño Gráfico, Editorial Trillas, México D.F.

- MORTARA GARAVELLI, Bice (1991): Manual de Retórica, Cátedra, Madrid.

- VV.AA (2005): “Titles designed by Saul Bass” en http://www.notcoming.com/saulbass/index2.php consultado el 3-11-2005

- SANZ MELGUIZO, Julio (2004): “Adherencia tipográfica. Dos ejemplos comparados de tipografía dinámica en el diseño de créditos” en VV.AA (2004): Ponencias Primer Congreso de Tipografia, ADCV, Valencia, pp. 66-69. 